\title{
Transposon mutagenesis of Nostoc sp. strain ATCC 29133, a filamentous cyanobacterium with multiple cellular differentiation alternatives
}

\author{
Michael F. Cohen, James G. Wallis, Elsie L. Campbell and John C. Meeks
}

Author for correspondence: J. C. Meeks. Tel: +1916 752 3346. Fax: +1916 7529014.

Section of Microbiology, Division of Biological Sciences, University of California, Davis, CA 95616, USA

\begin{abstract}
Nostoc sp. strain ATCC 29133 (PCC 73102 ; Nostoc 29133) is a symbioticallycompetent, facultatively heterotrophic, diazotrophic cyanobacterium with the capacity to differentiate specialized cells such as heterocysts, akinetes and hormogonial filaments. We have optimized several methods for physiological and molecular genetic analysis of Nostoc 29133. By use of a Tn5 derivative, Tn5-1063 ( $\mathrm{Km}^{\mathrm{r}} \mathrm{Bm} \mathrm{r} \mathrm{Sm}$ ), delivered by conjugation from Escherichia coli, antibiotic-resistant mutants of Nostoc 29133 were generated at a frequency of approximately $1 \times 10^{-6}, 0.4 \%$ of which expressed a nitrogen fixation (heterocyst) defective phenotype. Mutant strain UCD 328 was isolated after coculture of 86 Nostoc 29133::Tn5-1063 clones with the symbiotic plant partner, Anthoceros punctatus; strain UCD 328 expressed a symbiotic phenotype of increased frequency of hormogonia-dependent infection. The transposon and flanking genomic DNA was recovered from strain UCD 328, the mutation and phenotype reconstructed by homologous recombination in Nostoc 29133, and the transposition site identified from a Nostoc 29133 genomic library. Transposon mutagenesis has thus provided the means for isolation and identification of developmental and symbiotic-specific genes of Nostoc 29133.
\end{abstract}

Keywords: Nostoc sp. ATCC 29133, diazotrophic cyanobacterium, symbiotic cyanobacterium, transposon mutagenesis, homologous recombination

\section{INTRODUCTION}

Cyanobacteria are a morphologically diverse group of eubacteria, united by their characteristic oxygenic photoautotrophic mode of growth. In certain filamentous cyanobacterial genera classified in Sections IV and V (sensu Rippka et al., 1979), such as Nostoc, vegetative cells can mature in four developmental directions, depending upon the environmental growth conditions. First, they can divide upon reaching a critical size and perpetuate the vegetative growth cycle. Second, the vegetative cells can divide uncoupled from biomass increase or DNA replication to form transient hormogonial filaments

Abbreviations: Ap, ampicillin; ATCC, American Type Culture Collection; $\mathrm{Bm}$, bleomycin; $\mathrm{Chl} a$, Chlorophyll a; $\mathrm{Cm}$, chloramphenicol; $\mathrm{Em}$, erythromycin; Fix, nitrogen fixation; Fox, aerobic nitrogen fixation; $\mathrm{Km}$, kanamycin sulfate; MCR, deficient in restriction of DNA containing methylated adenine and cytosine residues; MDRS, methylation dependent restriction systems; Nm, neomycin sulfate; PCC, Pasteur Culture Collection; Sm, streptomycin; Sp, spectinomycin; Suc, sucrose; Sym, symbiotic competence.
(Damerval et al., 1991). Hormogonia formation can be induced by environmental conditions which include light quality and excess nutrients (Herdman \& Rippka, 1988). Third, a few or the entire population of vegetative cells can differentiate into akinetes (spores) which function in survival under environmental extremes (Herdman, 1987). A variety of environmental conditions, including nutrient (especially phosphate) deprivation, and autogenic production of a sporulation factor (Hirosawa \& Wolk, 1979), stimulate their formation. Fourth, under conditions of combined nitrogen deprivation a small fraction (3-10\%) of the vegetative cells will, in a defined spatial pattern along the filaments, differentiate into heterocysts which are specialized for nitrogen fixation in an oxic environment (Wolk, 1982). Thus, these filamentous cyanobacteria provide an experimental system for the study of how cells perceive, integrate and respond to environmental signals in the context of differentiation processes.

Techniques have been developed for genetic analysis of heterocyst differentiation and function in Anabaena sp. 
Table 1. Bacterial strains and plasmids

\begin{tabular}{|c|c|c|}
\hline $\begin{array}{l}\text { Strain or } \\
\text { plasmid }\end{array}$ & Relevant characteristics* & Reference(s) \\
\hline \multicolumn{3}{|l|}{ E. coli } \\
\hline $\mathrm{DH} 5 \alpha$ & $\operatorname{rec} A 1$ bsd $\mathrm{R} 17\left(\mathrm{r}_{\mathrm{K}}^{-} \mathrm{m}_{\mathrm{K}}^{-}\right)$end $A 1$ & Grant et al. (1990) \\
\hline DH5 $\alpha-M C R$ & $\begin{array}{l}\text { Genotype of DH5 } \alpha \text { and } m c r A \\
\Delta(m r r b s d M R S m c r B C)\end{array}$ & Grant et al. (1990) \\
\hline HB101 & $\operatorname{rec} A 13 \operatorname{bsdS} 20\left(\mathrm{r}_{\mathrm{B}}^{-} \mathrm{m}_{\mathrm{B}}^{-}\right)$ & \\
\hline \multicolumn{3}{|l|}{ Nostoc } \\
\hline $\begin{array}{l}\text { ATCC } 29133 \\
(\text { PCC } 73102)\end{array}$ & $\mathrm{Fix}^{+} \mathrm{Sym}^{+}$ & $\begin{array}{l}\text { Rippka et al. (1979); } \\
\text { Finderlin \& Meeks (1983) }\end{array}$ \\
\hline UCD 7801 & $\mathrm{Fix}^{+} \mathrm{Sym}^{+}$ & Enderlin \& Meeks (1983) \\
\hline $\mathrm{UCD} 328$ & $\begin{array}{l}\text { Superinfective Nostoc } \\
29133:: \operatorname{Tn} 5-1063 \text { strain, } \mathrm{Fix}^{+}\end{array}$ & This study \\
\hline UCD 339 & $\begin{array}{l}\text { pSCR } 3 \text { integrated by single } \\
\text { recombination in the genome }\end{array}$ & This study \\
\hline UCD 340 & $\begin{array}{l}\text { Reconstruction of the UCD } 328 \\
\text { mutation }\end{array}$ & This study \\
\hline \multicolumn{3}{|l|}{ Plasmids } \\
\hline pDUCA7 & $\begin{array}{l}\text { Cosmid shuttle vector with RK2 } \\
\text { and pDU1 oriVs, } \mathrm{Km}^{\mathrm{r}}\end{array}$ & $\begin{array}{l}\text { Buikema \& Haselkorn } \\
\text { (1991) }\end{array}$ \\
\hline pRK212.1 & $\begin{array}{l}\mathrm{RK} 2 \mathrm{Mu} \text { phage insertion/deletion } \\
\text { derivative, } \mathrm{Km}^{\mathrm{s}}\end{array}$ & Figurski et al. (1976) \\
\hline pRK2013 & $\begin{array}{l}\text { RK2 derivative with ColE1 oriV, } \\
\mathrm{Km}^{\mathrm{r}}\end{array}$ & $\begin{array}{l}\text { Figurski \& Helinski } \\
(1979)\end{array}$ \\
\hline pRK2073 & pRK2013::Tn7, Km $\mathrm{K}^{\mathrm{s}} \mathrm{Sp}^{\mathrm{r}}$ & Better \& Helinski (1983) \\
\hline pRL6 & $\begin{array}{l}\text { Shuttle vector with pMB1 and } \\
\text { pDU1 oriVs }\end{array}$ & Wolk et al. (1984) \\
\hline pRL443 & Spontaneous $\mathrm{Km}^{\mathrm{s}}$ mutant of $\mathrm{RP} 4$ & Elhai \& Wolk (1988a) \\
\hline pRL479 & S.A2/L.EHE2/C.C2, Ap ${ }^{r} \mathrm{Cm}^{r}$ & $\begin{array}{l}\text { Sec: Elhai \& Wolk (1988b) } \\
\text { for nomenclature }\end{array}$ \\
\hline pRL1063a & $\begin{array}{l}\operatorname{Tn} 5-1063, \mathrm{RK} 2 \text { oriT, } \mathrm{Bm}^{\mathrm{r}} \mathrm{Km}^{\mathrm{r}} \\
\mathrm{Sm}^{\mathrm{r}}\end{array}$ & Wolk et al. (1991) \\
\hline pRL1075 & $\begin{array}{l}\text { Used for reconstructing } \mathrm{Tn} 5-1063 \\
\text { insertions, } \mathrm{Cm}^{\mathrm{r}} \mathrm{Em}^{\mathrm{r}} \mathrm{Suc}^{\mathrm{s}}\end{array}$ & Black et al. (1993) \\
\hline pSCR1 & $\begin{array}{l}\text { Recovered } 19 \mathrm{~kb} \text { EcoR } V \mathrm{Tn} 5- \\
1063 \text { bearing fragment from } \\
\mathrm{UCD} 328, \mathrm{Bm}^{\mathrm{r}} \mathrm{Km}^{\mathrm{r}} \mathrm{Sm}^{\mathrm{r}}\end{array}$ & This study \\
\hline pSCR2 & $\begin{array}{l}\text { pSCR1 with NotI site filled in, } \\
\mathrm{Bm}^{r} \mathrm{Km}^{\mathrm{r}} \mathrm{Sm}^{\mathrm{r}}\end{array}$ & Th:s study \\
\hline pSCR3 & $\begin{array}{l}\text { pSCR2 with positive selection } \\
\text { cassette from pRL1075, Bm } \\
\mathrm{Cm}^{\mathrm{r}} \mathrm{Em}^{\mathrm{r}} \mathrm{Km}^{\mathrm{r}} \mathrm{Sm}^{\mathrm{r}} \mathrm{Suc}^{\mathrm{s}}\end{array}$ & This study \\
\hline pSCR4 & $\begin{array}{l}\text { Subclone of } 11 \mathrm{~kb} \text { EcoRV } \\
\text { fragment into pRL479 }\end{array}$ & This study \\
\hline pSCR5 & $\begin{array}{l}\text { Subclone of } 6.2 \mathrm{~kb} S p e \mathrm{I} \text { fragment } \\
\text { into pUC18 }\end{array}$ & This study \\
\hline pUC18 & pBR322-derived vector & Vieira \& Messing (1982) \\
\hline
\end{tabular}

strain PCC 7120 (Buikema \& Haselkorn, 1993; Wolk, 1991). However, Anabaena 7120 has limitations as an experimental system in developmental processes since it does not differentiate hormogonia or akinetes (Rippka et al., 1979).

Nostoc sp. strain ATCC 29133 (PCC 73102; Nostoc 29133) displays all of the cellular differentiation processes described above (Rippka et al., 1979). Unlike Anabaena 7120, Nostoc 29133 is also capable of photo- and dark-heterotrophic growth (Rippka et al., 1979). Moreover, Nostoc 29133 was originally isolated from symbiotic association with the cycad Macrozamia sp. (Rippka et al., 1979) and, via infection by hormogonia, can reconstitute a symbiotic 
association with the bryophyte Antboceros punctatus (Campbell \& Meeks, 1989; Enderlin \& Meeks, 1983) and the angiosperm Gunnera manicata (Johansson \& Bergman, 1994). When in association with $A$. punctatus, Nostoc spp. differentiate heterocysts at a frequency of about $45 \%$ of the total cells (Enderlin \& Meeks, 1983; Meeks, 1990), fix $\mathrm{N}_{2}$ under photo- and dark-heterotrophic conditions at a rate that is at least three- to fivefold higher than free-living cultures (Steinberg \& Meeks, 1991) and release approximately $80 \%$ of the fixed nitrogen as ammonium for growth of the associated eukaryotic tissue (Meeks et al., 1985).

We are interested in the interactions between Nostoc spp. and Anthoceros punctatus that regulate symbiotic cyanobacterial gene expression, enzyme activity and cellular differentiation, and whether such response systems differ from those operative in the free-living growth state. A screen to identify mutants with altered symbiotic competence, for which there is no positive selection, requires a population composed only of clones already known to harbour a mutation. Transposon mutagenesis has an advantage over chemical and UV mutagenesis since it meets this requirement by yielding an antibiotic-resistantmarked mutant population. We report here parameters for mutagenesis of Nostoc 29133 using a transposon, Tn 5 1063, which contains a promoterless $\ln x A B$ as a reporter gene, developed by Wolk et al. (1991) for use in Anabaena 7120. From a Nostoc 29133:: Tn5-1063 strain having an increased initial infection frequency of $A$. punctatus, the transposon and flanking genomic sequences were recovered and the mutation reconstructed by homologous recombination of the recovered DNA.

\section{METHODS}

Cultures and media. The bacterial strains and plasmids used in this study are listed in Table 1. Escherichia coli strains were routinely cultured in Luria-Bertani (LB) broth (Sambrook et al., 1989) and cell concentrations determined by measuring the optical density of cultures at $600 \mathrm{~nm}\left(\mathrm{OD}_{600}\right)$. Sources and culture conditions for symbiont-free and Nostoc-associated Anthoceros punctatus, and all free-living Nostoc strains, were described previously (Enderlin \& Meeks, 1983). The basal medium for growth of Nostoc was that of Allen \& Arnon (1955) (AA) supplemented with $5 \mathrm{mM}$ MOPS, $\mathrm{pH} 7 \cdot 8(-\mathrm{N})$, and, when specified, $2.5 \mathrm{mM} \mathrm{NH} \mathrm{mH}_{4}(+\mathrm{N})$; it was used at full strength when solidified with $1 \%(\mathrm{w} / \mathrm{v})$ agar (purified using the methods of Braun \& Wood, 1962) or diluted fourfold in liquid culture (AA/4). Chlorophyll $a(\mathrm{Chl} a)$ in methanolic extracts was quantified as described previously (Meeks et al., 1983). To select for resistance conferred by the $n p t$ gene, kanamycin $(\mathrm{Km} ; 12.5$ or $25 \mu \mathrm{g} \mathrm{ml}^{-1}$ ) was used for $E$. coli and neomycin $(\mathrm{Nm}$; $10 \mu \mathrm{g} \mathrm{ml}^{-1}$ ) was used for Nostoc 29133.

DNA isolations and manipulations. Small-scale preparations of plasmid DNA from E. coli were done using standard methods. Large-scale plasmid purifications from $E$. coli were carried out using a commercial kit (Qiagen). DNA restriction enzymes were obtained from New England Biolabs. Hybridization of radiolabelled probes to DNA immobilized on nylon membranes (Gene Screen Plus; Dupont NEN Products) was done as described by Sambrook et al. (1989) using $50 \%$ (v/v) formamide.
Hybridization probes were prepared by random priming (5 Prime -3 Prime, Inc.) using $\left[\alpha^{32} \mathrm{P}\right] \mathrm{dCTP}$ (Dupont, NEN).

Nostoc total DNA was isolated by a method based on that of Ausubel et al. (1987). Cells were collected from a $50 \mathrm{ml}$ $\mathrm{AA} / 4+\mathrm{N}$ culture having a density of $\leqslant 5 \mu \mathrm{g} \mathrm{Chl} \mathrm{a} \mathrm{ml} \mathrm{mb}^{-1}$ by centrifugation in a clinical centrifuge at $1000 \mathrm{~g}$ for $5 \mathrm{~min}$. The supernatant was discarded and the cells washed twice with $5 \mathrm{M}$ $\mathrm{NaCl}$. The pellet from the final wash was resuspended in TE buffer (10 mM Tris/ $\mathrm{HCl}, 1 \mathrm{mM}$ EDTA, $\mathrm{pH} 8)$ to give a total volume of $1 \mathrm{ml}$ and the cells stored frozen overnight at $-20^{\circ} \mathrm{C}$. After thawing by immersion in a water bath at room temperature, $1 \mathrm{ml}$ of a $20 \mathrm{mg} \mathrm{ml}^{-1}$ lysozyme solution in TE was added to the cell suspension. Following incubation at $37^{\circ} \mathrm{C}$ for $1 \mathrm{~h}$ with gentle shaking, $0.5 \mathrm{ml} 0.5 \mathrm{M}$ EDTA, pH 8.0, was added, and the cells were lysed by addition of $1 \mathrm{ml}$ of a $2 \mathrm{mg} \mathrm{ml}^{-1}$ Proteinase $\mathrm{K}$ solution in TE, plus $0.1 \mathrm{ml} 20 \%(\mathrm{w} / \mathrm{v})$ $\mathrm{SDS}$, followed by incubation as above for $1 \mathrm{~h}$. After lysis, $0.6 \mathrm{ml}$ $5 \mathrm{M} \mathrm{NaCl}$ was added and the suspension mixed gently; $0.45 \mathrm{ml}$ of a $10 \%(\mathrm{w} / \mathrm{v})$ solution of hexadecyltrimethylammonium bromide (CTAB) in $0.7 \mathrm{M} \mathrm{NaCl}$ was added, and the suspension was mixed and incubated for $10 \mathrm{~min}$ in a $65^{\circ} \mathrm{C}$ water bath. The cell debris was pelleted for $5 \mathrm{~min}$ at $13000 \mathrm{~g}$. The supernatant solution was extracted once with chloroform and nucleic acids were precipitated with ethanol. The pellet was resuspended in $0.5 \mathrm{ml} \mathrm{TE}$ and extracted one to three times with phenol/ chloroform until the interface was clear. The aqueous phase was precipitated and the pellet washed once with $70 \%(\mathrm{v} / \mathrm{v})$ ethanol and dried under vacuum. The resulting pellet was resuspended

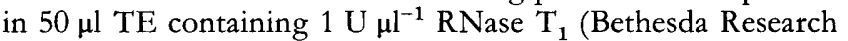
Laboratories).

Plasmids were isolated from $50 \mathrm{ml}$ liquid cultures of Nostoc 29133 grown under $\mathrm{Nm}$ selection and having Chl $a$ concentrations of approximately $5 \mu \mathrm{g} \mathrm{ml}^{-1}$. Nostoc cells were harvested as before, washed twice with $5 \mathrm{M} \mathrm{NaCl}$ and then resuspended in $2 \mathrm{ml}$ TE. Lysozyme was added to a final concentration of $5 \mathrm{mg} \mathrm{ml}^{-1}$. After mixing, the tube was incubated with gentle shaking for $2 \mathrm{~h}$ at $37^{\circ} \mathrm{C}$ then Triton X-100 $(0.5 \mathrm{ml}$ of a $20 \%$, $\mathrm{v} / \mathrm{v}$, solution) was added to lyse the cells. The resulting solution was made up to a concentration of $1 \mathrm{M} \mathrm{NaCl}$ by the addition of cold $5 \mathrm{M} \mathrm{NaCl}$ and the suspension was stored overnight at $4{ }^{\circ} \mathrm{C}$. The suspension was cleared by centrifugation at $1000 \mathrm{~g}$ for $10 \mathrm{~min}$ and the supernatant was extracted with phenol/ chloroform as above. Nucleic acids in the final aqueous phase were precipitated with $0.6 \mathrm{vol}$. of 2 -propanol followed by centrifugation at $12000 \mathrm{~g}$ for $10 \mathrm{~min}$. The pellet was washed twice with $70 \%$ ethanol, vacuum dried, and resuspended in glass-distilled water.

Genomic library construction and screening. High-molecularmass genomic DNA of Nostoc 29133 was sheared randomly and the ends were blunted by incubation with mung bean nuclease. EcoRI-XmnI adapters were ligated to the ends and these adapted inserts were ligated into EcoRI-digested cosmid shuttle vector pDUCA7 (Buikema \& Haselkorn, 1991). The ligated material was packaged into $\lambda$ phage using the methods of Ish-Horowicz \& Burke (1981) and transfected into E. coli strain DH5 $\alpha-\mathrm{MCR}$. A total of 16200 clones were pooled and stored as a massed library. Restriction analysis of 23 randomly chosen clones showed an average insert size of $28 \mathrm{~kb}$. A total of 2112 clones was stored individually in microtitre plates and patched onto nylon membranes for hybridization screening. The patched colonies were lysed on the membrane according to Sambrook $e t$ al. (1989) after overnight growth on LB agar containing $12.5 \mu \mathrm{g}$ $\mathrm{Km} \mathrm{m}^{-1}$.

Transposon mutagenesis. A protocol for transposon muta- 
genesis of Anabaena 7120 (Wolk et al., 1991) was adapted for use with Nostoc 29133. Tri-parental plate matings were conducted on sterile conjugation filters (Millipore HATF 082) lying on agar plates containing $\mathrm{AA}+\mathrm{N}+0.5 \%(\mathrm{v} / \mathrm{v}) \mathrm{LB}$ broth. In preparation for conjugation, Nostoc filaments were fragmented by sonic cavitation to a length of four to six cells per filament, allowed to recover by incubation under growth conditions for at least $6 \mathrm{~h}$ in $50 \mathrm{ml} \mathrm{AA} / 4+\mathrm{N}$ and were concentrated to approximately $75 \mu \mathrm{g} \mathrm{Chl} a \mathrm{ml}^{-1}$ immediately before mating. $E$. coli was prepared for mating by combining in a centrifuge tube equal numbers of the donor strain (DH5 $\alpha$ containing the transposon-bearing plasmid pRL1063a) and the conjugal strain (HB101 containing the conjugal plasmid pRK2013) both grown to concentrations of less than $1.0 \mathrm{OD}_{600}$ in LB containing $25 \mu \mathrm{g}$ $\mathrm{Km} \mathrm{m}^{-1}$. The cells were pelleted by centrifugation at $2000 \mathrm{~g}$ for $10 \mathrm{~min}$ and resuspended to a final concentration of $9-10 \mathrm{OD}_{600}$ units in LB. For each conjugation filter, $0.5 \mathrm{ml}$ of the E. colt mixture was combined in a microfuge tube with $0.5 \mathrm{ml}$ of the concentrated Nostoc 29133 cell suspension. The E. coli/Nostoc 29133 mixture was then centrifuged at $4000 \mathrm{~g}$ for $30 \mathrm{~s}$. The supernatant was aspirated, leaving approximately $150 \mu$ lotal volume in the microfuge tube. The pellet was resuspended and immediately spread on the filter. The filter-plates were incubated at $28{ }^{\circ} \mathrm{C}$ and low light intensity $\left(1.5 \mathrm{~W} \mathrm{~m}^{-2}\right)$ in air plus $1 \%(\mathrm{v} / \mathrm{v})$ $\mathrm{CO}_{2}$ for $16-24 \mathrm{~h}$ to allow for conjugal mating. To allow the expression of antibiotic resistance, the filters were transferred to fresh $A A+N 1 \%$ agar plates without $L B$ and incubated at low light intensity for an additional $2 \mathrm{~d}$ and then moved to $8 \mathrm{~W} \mathrm{~m}^{-2}$ illumination for another $1-2 \mathrm{~d}$ incubation. The filters were ther. transferred to selective $\mathrm{AA}+\mathrm{N}$ plates containing $10 \mu \mathrm{g} \mathrm{Nm}$ $\mathrm{ml}^{-1}$ and $1 \mu \mathrm{g} \mathrm{Sm} \mathrm{ml} \mathrm{g}^{-1}$. At approximately 1 week intervals the filters were transferred to fresh selective medium. Mutant: appeared as colonies after 10-21 d. To screen for aerobic nitrogen-fixation mutants (Fox ${ }^{-}$; sensu Ernst et al., 1992), filters bearing mutant colonies were transferred to $A A-N$ plates. Colonies that developed yellowing edges after about $7 \mathrm{~d}$ were patched on $A A-N$ and $A A+N$ media.

Quantification of conjugation frequency. For the purpose of estimating exconjugant frequencies that were dependent on the conjugal plasmid, matings were conducted as described above except that a $0.2 \mathrm{OD}_{600}$ mixture of $E$. coli was used and filters were not transferred to selective medium. Instead, the filters were flooded with fresh liquid medium and the mixed Nostor and $E$. coli cells were collected, centrifuged and resuspended in an exact volume of fresh medium. Dilutions of the cell suspensions were plated on both selective and non-selective media, and colonies counted after 2 weeks.

Recovery of DNA flanking the transposon in strain UCD 328 and reconstruction of the mutation. The transposon Tn 5-1063 contains an oriV(p15A) which allows for recovery of the transposon with the DNA flanking its insertion site in the Nostoc genome (Wolk et al., 1991). pSCR1, containing $11 \mathrm{~kb}$ of Nostoc DNA contiguous with the $7.8 \mathrm{~kb}$ transposon, was recovered from an EcoRV digest of strain UCD 328 genomic DNA using the strategy of Black \& Wolk (1994). To make pSCR2, a frameshift mutation was introduced into the transposase gene of pSCR 1 by filling in a unique Not site. pSCR.3 was constructed by ligating an SpeI pSCR2 fragment, encompassing the transposon and $6.2 \mathrm{~kb}$ of Nostoc flanking DNA, to a pRL1075 sacB-containing SpeI fragment (Black et al., 1993). To reconstruct the mutation, pSCR3 was mated into Nostoc 29133 cells using the conjugation method described above. $\mathrm{Nm}^{\mathrm{r}}$ clones were grown in liquid, sonicated and plated on $A A$ containing $10 \mu \mathrm{g} \mathrm{Nm} \mathrm{ml}^{-1}$ and $5 \%(\mathrm{w} / \mathrm{v}$ ) sucrose to select for double recombinants (Cai \& Wolk, 1990).
Luciferase filter assay. Filters containing mutant colonies were placed on a $0.5 \mathrm{ml}$ pool of liquid medium on a glass plate. This was overlaid with a thin glass plate streaked on the filter-facing side with $2 \mu \mathrm{l}$ decyl aldehyde (Aldrich) per filter, leaving a $1 \mathrm{~mm}$ space between the two plates so as not to crush the Nostor colonies. In a darkroom, pre-flashed X-ray film was placed on top of the apparatus and exposed for $3-5 \mathrm{~h}$. To examine the Fox mutants for changes in luciferase activity induced by nitrogen deprivation, each mutant was patched to two filters and incubated under light for $7 \mathrm{~d}$. One filter was then transferred to an $\mathrm{AA}-\mathrm{N}$ plate and the other to fresh $\mathrm{AA}+\mathrm{N}$; the plates were incubated for an additional $2 \mathrm{~d}$ before subjecting them to the filter assay.

Cell differentiation assays. Cultures were induced to form akinetes by subculturing into $\mathrm{AA} / 4+\mathrm{N}$ without inorganic phosphate. To induce hormogonia, Antboceros punctatus growthconditioned medium was obtained by transferring approximately $5 \mathrm{~g}$ (fresh weight) of gametophyte tissue (washed twice with $100 \mathrm{ml} \mathrm{AA} / 4$ ) into $50 \mathrm{ml} \mathrm{AA} / 4$ without supplementation. Samples of $0.2 \mathrm{ml}$ from Nostoc cultures were combined with $2.3 \mathrm{ml}$ of $A$. punctatus conditioned medium in culture tubes and incubated at 100 r.p.m. at room temperature and $8 \mathrm{~W} \mathrm{~m}$. After 24-36 h, filaments were examined microscopically for hormogonia formation.

\section{RESULTS AND DISCUSSION}

\section{Nostoc 29133 as an experimental strain}

In addition to the three developmental alternatives, heterotrophic growth and the ability to establish a symbiotic association with $A$. punctatus, two other considerations influenced our choice of Nostoc 29133 as an experimental strain. First, Nostoc 29133 is reported to have no type II endonuclease activity (Lambert \& Carr, 1984; Shestakov \& Reaston, 1987). This deficiency is an advantage when attempting to transfer DNA into the strain, obviating the in vivo methylation used in Anabaena strains (Elhai \& Wolk, 1988b). Second, the lack of endogenous plasmids in Nostoc 29133 (Houmard \& Tandeau de Marsac, 1988) eases the identification and recovery of vector plasmids introduced into the strain.

\section{Conjugation procedures}

Initial attempts at introducing the transposon Tn 5-1063 into Nostoc 29133, using the conjugation protocol designed for use in Anabaena 7120 (Elhai \& Wolk, 1988b), yielded only one mutant out of three filter matings. Moreover, conjugation frequencies of only about $5 \times 10^{-7}$ were observed using this same protocol to introduce a pDU1-based shuttle vector, pRL6, into Nostoc 29133 (Wallis, 1993). When Nostoc 29133 cell suspensions were mixed with $E$. coli suspensions at the concentration used with Anabaena 7120 (Elhai \& Wolk, 1988b), the Nostor 29133 bleached rapidly on non-selective medium; Nostoc 29133 by itself did not bleach. For conjugal transfer of pRL1063a, an approximately 20 -fold reduction in the reported $E$. coli concentration gave the highest frequency of resultant Nostoc 29133:: Tn5-1063 colonies. Control matings transferring pDUCA7 from $E$. coli donors to $E$. coli recipients showed that exponential cultures of $E$. coli 
mated at a nearly 10-fold higher frequency than stationaryphase cultures (data not shown); the growth phase of Nostoc 29133 had no influence on the frequency of conjugation (Wallis, 1993). Therefore, for conjugal matings between Nostoc 29133 and E. coli, exponentialphase $E$. coli was used and the cells plated immediately after mixing.

An increase in conjugation frequency was also obtained by use of a different conjugal plasmid. The plasmid, pRK2013, contains the conjugal transfer functions of RK2 inserted into a derivative of plasmid ColE1, and is dependent on the ColE1 origin of replication (Figurski \& Helinski, 1979). Control mating experiments between $E$. coli strains demonstrated that pDUCA 7 was mobilized 50fold more effectively by pRK2073, a $\mathrm{Km}^{\mathrm{s}}$ derivative of pRK2013, than by plasmids pRL443 and pRK212.1, which use the RK2/RP4 origin of replication (data not shown). When Nostoc 29133 was the recipient, mating via pRK2073 yielded a frequency of exconjugants per viable c.f.u. $\left(5.5 \times 10^{-4} \mathrm{Km}^{\mathrm{r}}\right.$ per c.f.u.) that was at least 50 -fold higher than the frequency using pRL443 $\left(<9 \cdot 1 \times 10^{-6}\right.$ $\mathrm{Km}^{\mathrm{r}}$ per c.f.u.). The improved mobilization may be explained by the higher copy number of pRK2073 compared to the RK2/RP4-based conjugal plasmids, perhaps producing more of the proteins necessary for the conjugation process. Compatibility between the ColE1 and the RK2/RP4 origins of replication allows both the conjugal plasmid and the mobilized vector plasmid to reside in the same $E$. coli cell, which may also contribute to the observed increase in the frequency of transfer.

\section{Nostoc 29133 DNA isolation and library construction}

To obtain DNA for the construction of a genomic library and for the recovery of $\operatorname{Tn} 5-1063$ transposition sites, a method of total DNA isolation from Nostoc 29133 was devised that reliably gave high yields. The major modification of the DNA isolation method of Ausubel et al. (1987) was the introduction of two preliminary washes with $5 \mathrm{M}$ $\mathrm{NaCl}$ to remove Nostoc exopolysaccharides, which appear to inhibit the extent of cell lysis in subsequent steps. The exopolysaccharide content of the starting cellular material can be reduced by harvesting dilute cultures $(\leqslant 5 \mu \mathrm{g} \mathrm{Chl}$ $a \mathrm{ml}^{-1}$ ) grown in ammonium-supplemented medium. This method routinely yielded approximately $1 \mu \mathrm{g}$ DNA per $2 \mu \mathrm{g} \mathrm{Chl} a$, and has been applied to some other Nostoc strains with similar success (Wallis, 1993).

Before introducing Nostoc 29133 DNA into E. coli, restriction of the DNA by the methylation-dependent restriction systems (MDRS) which are present in many $E$. coli $\mathrm{K} 12$ strains was examined; MDRS restrict DNA introduced into $E$. coli cells only if that DNA is methylated at specific sequences (Raleigh, 1992). A method for isolating plasmid DNA from Nostoc 29133 was necessary to perform this experiment. Several published methods specific to cyanobacteria (Felkner \& Barnum, 1988; Potts, 1989; Stuttzman \& Gendel, 1985) failed to yield usable DNA, principally because few Nostoc 29133 cells were lysed. As with the total DNA isolation protocol, pre-
Table 2. Effect of methylation dependent restriction systems on transformation frequency

\begin{tabular}{|llrc|}
\hline $\begin{array}{l}\text { Source of } \\
\text { pDUCA7 }\end{array}$ & $\begin{array}{c}\text { E. coli } \\
\text { strain } \\
\text { transformed }\end{array}$ & $\begin{array}{c}\text { Km colonies } \\
\text { per } \mu \text { g DNA }\end{array}$ & $\begin{array}{c}\text { Ratio DH5 } \alpha \text { / } \\
\text { DH } \alpha \text {-MCR }\end{array}$ \\
\hline E. coli HB101 & DH5 $\alpha$ & $7 \cdot 1 \times 10^{-2}$ & 0.91 \\
& DH5 $\alpha-\mathrm{MCR}$ & $7.9 \times 10^{-2}$ & \\
Nostoc 29133 & $\mathrm{DH} 5 \alpha$ & $<1.0 \times 10^{-5}$ & $<0.005$ \\
& DH5 $\alpha-\mathrm{MCR}$ & $0.2 \times 10^{-3}$ & \\
\hline
\end{tabular}

liminary $5 \mathrm{M} \mathrm{NaCl}$ washes in the plasmid preparation protocol improved subsequent cell lysis. This protocol yielded $17 \mu \mathrm{g}$ pDUCA7 DNA per $\mu \mathrm{g} \mathrm{Chl} a$.

For a comparison of transformation efficiencies, E. coli strains DH5 $\alpha$ and DH5 $\alpha$-MCR were transformed with vector pDUCA7 isolated from Nostoc 29133. These E. coli strains are isogenic except that the loci coding for the MDRS have been deleted from strain DH5 $\alpha$-MCR (Grant et al., 1990). In control experiments plasmid DNA isolated from E. coli $\mathrm{HB} 101$ transformed the two DH5 $\alpha$ strains at nearly equal efficiencies. However, plasmid DNA isolated from Nostoc 29133 transformed DH $5 \alpha$-MCR with at least a 200 -fold greater frequency than it transformed $\mathrm{DH} 5 \alpha$ (Table 2). To bypass this apparent restriction barrier, a Nostoc 29133 genomic DNA library, constructed in pDUCA7 and packaged in $\lambda$ phage, was transfected into $E$. coli strain DH5 $\alpha-\mathrm{MCR}$. This genomic library has served as a source for wild-type DNA corresponding to the transposition sites of all Nostoc 29133:: Tn5-1063 mutants so far recovered from the genome (unpublished observations), including that of strain UCD 328 discussed below.

\section{Mutagenesis and mutant phenotypes}

Tri-parental filter matings using the conjugal plasmid pRK2013 to introduce Tn5-1063 into Nostoc 29133 were conducted on $\mathrm{AA}+\mathrm{N}$ to allow the growth of any resulting nitrogen fixation and nitrate assimilation mutants. The procedure resulted in a frequency of 1.0 $( \pm 0 \cdot 8) \times 10^{-6}$ [mean ( $\left.\left.\pm \mathrm{SD}\right), n=7\right]$ Nostoc 29133:: Tn51063 colonies per viable Nostoc cell in the mating mixture (based on a value of $1.75 \times 10^{-13} \mathrm{~g} \mathrm{Chl} a$ per viable cell). The yield of resultant colonies per filter is about five times lower than that reported for $\operatorname{Tn} 5-1063$ mutagenesis of Anabaena 7120 (Wolk et al., 1991).

Of $5 \cdot 1 \times 10^{3}$ mutant colonies screened, $14 \mathrm{Fox}^{-}$mutants, all with discernible heterocyst defects, were identified. Two Fox ${ }^{-}$strains had a fragmented, short-filament phenotype in the presence or absence of combined nitrogen. Symbiotic competence was retained in four Fox ${ }^{-}$strains; it has been shown previously that for strain UCD 223, a Nostoc 29133 Fox $^{-}$mutant generated by chemical mutagenesis, the microaerobic symbiotic cavities 


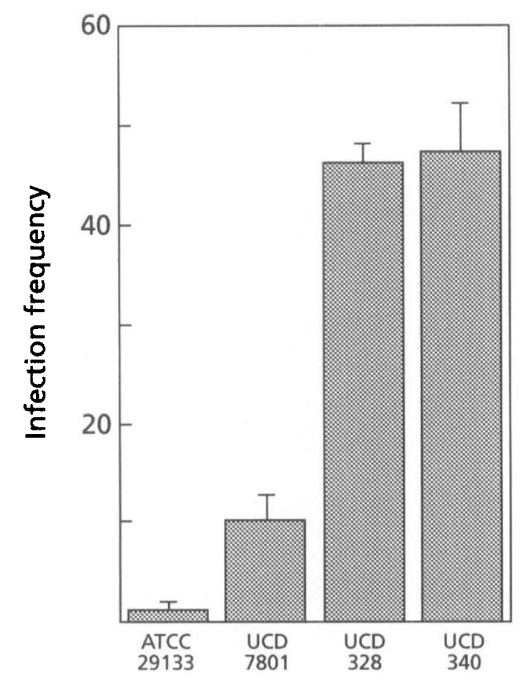

Fig. 1. Relative infection frequencies of Anthoceros punctatus by various Nostoc strains. Nostoc cells representing $30 \mu \mathrm{g}$ or $60 \mu \mathrm{g} \mathrm{Chl} \mathrm{a} \mathrm{were} \mathrm{added} \mathrm{to} 2-3 \mathrm{~g}$ fresh weight of $A$. punctatus gametophyte tissue in $50 \mathrm{ml}$ medium lacking combined nitrogen. After $14 \mathrm{~d}$ co-culture the plant tissue was washed and samples were removed for the quantification of symbiotic colonies. Infection frequencies were calculated as the mean number \pm SD of symbiotic colonies per $\mathrm{mg}$ tissue dry weight per unit of Nostoc cells added (as $\mu \mathrm{g} \mathrm{Chl} \mathrm{a)} \mathrm{for:} \mathrm{Nostoc} \mathrm{ATCC} \mathrm{29133,}$ $n=3$; UCD 7801, $n=2$; UCD 328, $n=4$; and UCD 340, $n=4$. The reported frequencies are normalized to the infection frequency of Nostoc ATCC 29133.

of Anthoceros punctatus can replace the physiological function of the heterocyst envelope (Campbell \& Meeks, 1992). The heterocyst envelope polysaccharide of two Anabaena strains is apparently the same as that found in their respective akinetes (Cardemil \& Wolk, 1976, 1981). We examined the akinetes of Fox ${ }^{-}$Nostoc 29133::Tn51063 strains which had microscopically observable defects in their heterocyst envelopes, but found no corresponding defects in the continuity of their akinete envelopes.

The promoterless bacterial luciferase genes, $\operatorname{lu} x A B$, of Tn5-1063 can form transcriptional fusions to the Nostoc 29133 genome upon transposition. To screen for transpositions within transcribed regions of the genome, several filters containing mutant colonies were assayed for luciferase activity by exposure to X-ray film. Light emission was detected from 30\% (313/1063) of the mutant colonies when grown on minimal medium with or without $\mathrm{NH}_{4}^{+}$. The $14 \mathrm{Fox}^{-}$mutant colonies were separately screened for changes in luciferase activity after $2 \mathrm{~d}$ of ammonium deprivation; one group of seven mutants showed increased levels of expression, a second group of five mutants showed no change and a third group of two mutants showed a decrease.

Of 86 randomly chosen $\mathrm{Fix}^{+}$Nostoc 29133::Tn5-1063 strains tested for symbiotic competence, one (strain UCD 328) was found to have a high initial frequency of infection. After 2 weeks of co-culture, strain UCD 328 infected Anthoceros punctatus at about a 50-fold higher frequency than the parental Nostoc 29133 strain and fivefold higher than Nostoc sp. strain UCD 7801 (Fig. 1), our original isolate from $A$. punctatus (Enderlin \& Meeks, 1983). Strain UCD 328 was found to be more sensitive than wild-type Nostoc 29133 to a hormogonia-inducing factor in $A$. punctatus growth-conditioned medium (M. F. Cohen \& J. C. Meeks, unpublished). Furthermore, unlike other Nostoc strains, which may grow to a high density in the medium surrounding the plant (Enderlin \& Meeks, 1983), epiphytic growth of strain UCD 328 was severely reduced; strain UCD 328 showed no obvious growth defect in the free-living state.

\section{Reconstruction of the strain UCD 328 mutation}

Southern blots of total EcoRV-digested DNA from strain UCD 328, probed with HincII-digested pRL1063a, showed a single $19 \mathrm{~kb}$ band of hybridizing DNA (data not shown), implying that the genome bears only one copy of the transposon. The mutation was reconstructed by insertion mutagenesis to confirm that the phenotype of strain UCD 328 was a result of the Tn5-1063 insertion. The positive selection plasmid, pSCR3, containing Tn51063 with an inactivated transposase gene in a $6.2 \mathrm{~kb}$ Nostoc 29133 SpeI fragment (Fig. 2), was introduced into Nostoc 29133 by conjugation. Single recombination of pSCR3 into the Nostoc 29133 genome gave rise to a $\mathrm{Nm}^{\mathrm{r}}$ $\mathrm{Em}^{\mathrm{r}} \mathrm{Suc}^{\mathrm{s}}$ phenotype. A second recombination on the opposite side of the transposon resulted in a $\mathrm{Nm}^{\mathrm{r}} \mathrm{Em}^{\mathbf{s}}$ Suc ${ }^{r}$ phenotype and was selected by plating on sucrosecontaining medium (Cai \& Wolk, 1990). Southern analysis confirmed single recombination (strain UCD 339) and double recombination (strain UCD 340) of pSCR3 at the same locus as the transposition site in strain UCD 328 (Fig. 3). Strain UCD 340 was co-cultured with Anthoceros punctatus and found to have an initial infection frequency near that of strain UCD 328 (Fig. 1). A $2 \mathrm{~kb}$ fragment of DNA flanking the transposition site of strain UCD 328

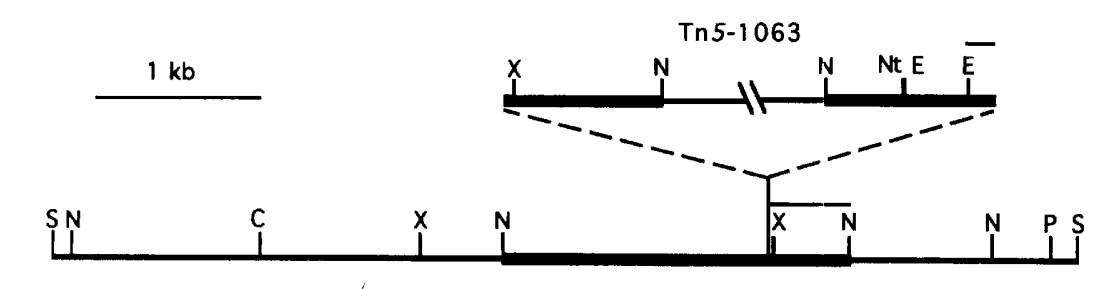

Fig. 2. Partial restriction map of the $6.2 \mathrm{~kb}$ Spel genomic fragment bearing the Tn51063 insertion in strain UCD 328. Restriction sites are for Clal (C), Eagl (E), Nhel (N), Notl (Nt), Pvull (P), Spel (S) and Xbal (X). Bold lines indicate the Nhel fragments which hybridize to the Eagl-Nhel pSCR1 fragment (overlined) that was used to probe the Southern blot shown in Fig. 3. 


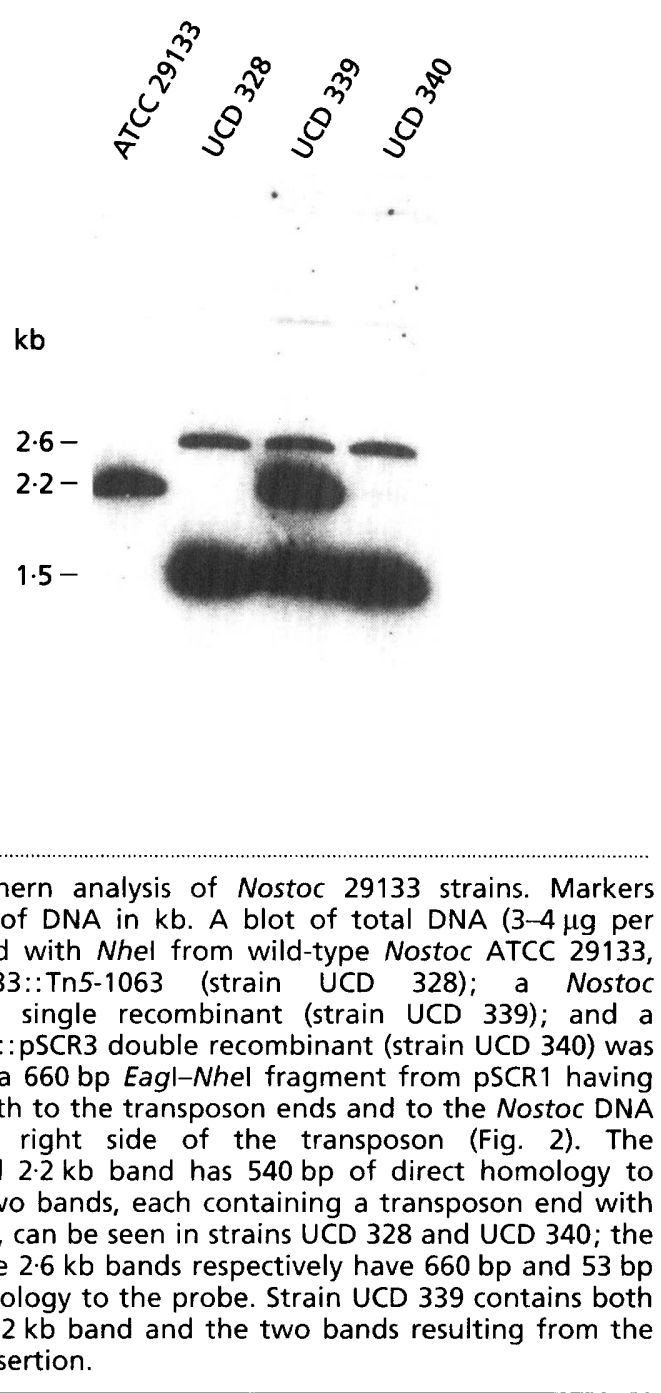

Fig. 3. Southern analysis of Nostoc 29133 strains. Markers indir ate size of DNA in $\mathrm{kb}$. A blot of total DNA (3-4 $\mu \mathrm{g}$ per lanel digested with Nhel from wild-type Nostoc ATCC 29133, Nostoc 29133::Tn5-1063 (strain UCD 328); a Nostoc 29133: :pSCR3 single recombinant (strain UCD 339); and a Nostoc 29133::pSCR3 double recombinant (strain UCD 340) was probed with a $660 \mathrm{bp}$ Eagl-Nhel fragment from pSCR 1 having homology both to the transposon ends and to the Nostoc DNA flanking the right side of the transposon (Fig. 2). The unirterrupted $2.2 \mathrm{~kb}$ band has $540 \mathrm{bp}$ of direct homology to the srobe. Two bands, each containing a transposon end with flanxing DNA, can be seen in strains UCD 328 and UCD 340; the $1.5 \mathrm{~kb}$ and the $2.6 \mathrm{~kb}$ bands respectively have $660 \mathrm{bp}$ and $53 \mathrm{bp}$ of direct homology to the probe. Strain UCD 339 contains both a wild type $2 \cdot 2 \mathrm{~kb}$ band and the two bands resulting from the transposon insertion.

hybridized strongly to three cosmid clones out of 2112 clones from the genomic library. Southern analysis revealed the hybridizing stretch of DNA to be on an $11 \mathrm{~kb}$ EcoRV fragment common to all three cosmids. Restriction mapping of a $6.2 \mathrm{~kb} S p e I$ fragment (Fig. 2), internal to the $11 \mathrm{~kb}$ EcoRV fragment, showed it to be identical to the Nostoc DNA flanking the transposition site in pSCR3.

This study demonstrates that transposon and insertion mutants of Nostoc 29133 can be generated. Such mutants will be useful in investigations of its developmental alternatives and its symbiotic interactions with plant tissues. We are currently characterizing the physiology and molecular genetics of strain UCD 328.

\section{ACKNOWLEDGEMENTS}

This work was supported by the California Agricultural Experiment Station (project CAD*3620-H) and by the U. S. National Science Foundation (Grant IBN 9206139). M.F.C. gratefully acknowledges support of a Floyd and Mary Schwall Fellowship in Medical Research. We thank Todd Black, Jeff
Elhai and Peter Wolk for their advice and plasmids, and Tom Hanson and Michael Summers for their critical reading of the manuscript.

\section{REFERENCES}

Allen, M. B. \& Arnon, D. I. (1955). Studies on nitrogen-fixing bluegreen algae. I. Growth and nitrogen fixation by Anabaena cylindrica Lemm. Plant Physiol 30, 366-372.

Ausubel, F. M., Brent, R., Kingston, R. E., Moore, D. D., Seidman, J. G., Smith, J. A. \& StruhI, K. (1987). Current Protocols in Molecular Biology. New York: Green Publishing Associates \& WileyInterscience.

Better, M. \& Helinski, D. R. (1983). Isolation and characterization of the $\operatorname{rec} A$ gene of Rhizobium meliloti. J Bacteriol 155, 311-316.

Black, T. A. \& Wolk, C. P. (1994). Analysis of a $\mathrm{Het}^{-}$mutation in Anabaena sp. strain PCC 7120 implicates a secondary metabolite in the regulation of heterocyst spacing. J Bacteriol 176, 2282-2292.

Black, T. A., Cai, Y. \& Wolk, C. P. (1993). Spatial expression and autoregulation of het $\mathrm{R}$, a gene involved in the control of heterocyst development in Anabaena. Mol Microbiol 9, 77-84.

Braun, A. C. \& Wood, H.N. (1962). On activation of certain essential biosynthetic systems in cells of Vinca rosea L. Proc Natl Acad Sci US A 48, 1776-1782.

Buikema, W. J. \& Haselkorn, R. (1991). Isolation and complementation of nitrogen fixation mutants of the cyanobacterium Anabaena sp. strain PCC 7120. J Bacteriol 173, 1879-1885.

Buikema, W. J. \& Haselkorn, R. (1993). Molecular genetics of cyanobacterial development. Annu Rev Plant Pbysiol Plant Mol Biol $44,33-52$.

Cai, Y. \& Wolk, C. P. (1990). Use of a conditionally lethal gene in Anabaena sp. strain PCC 7120 to select for double recombinants and to entrap insertion sequences. $J$ Bacteriol 172, 3138-3145.

Campbell, E. L. \& Meeks, J. C. (1989). Characteristics of hormogonia formation by symbiotic Nostoc spp. in response to the presence of Anthoceros punctatus or its extracellular products. Appl Environ Microbiol 55, 125-131.

Campbell, E. L. \& Meeks, J. C. (1992). Evidence for plant-mediated regulation of nitrogenase expression in the Antboceros-Nostoc symbiotic association. J Gen Microbiol 138, 473-480.

Cardemil, L. \& Wolk, C.P. (1976). The polysaccharides from heterocyst and spore envelopes of a blue-green algae. J Biol Chem 251, 2967-2975.

Cardemil, L. \& Wolk, C.P. (1981). Polysaccharides from the envelopes of heterocysts and spores of the blue-green algae Anabaena variabilis and Cylindrospermum licheniforme. J Pbycol 17 , 234-240.

Damerval, T., Guglielmi, G., Houmard, J. \& Tandeau de Marsac, N. (1991). Hormogonium formation in the cyanobacterium Calotbrix: a photoregulated developmental process. Plant Cell 3, 191-201.

Elhai, J. \& Wolk, C. P. (1988a). A versatile class of positive-selection vectors based on the nonviability of palindrome-containing plasmids that allows cloning into long polylinkers. Gene 68, 119-138.

Elhai, J. \& Wolk, C. P. (1988b). Conjugal transfer of DNA to cyanobacteria. Methods Enzymol 167, 747-754.

Enderlin, C. S. \& Meeks, J. C. (1983). Pure culture and reconstitution of the Anthoceros-Nostoc symbiotic association. Planta 158, 157-165.

Ernst, A., Black, T., Cai, Y., Panoff, J.-M., Tiwari, D. N. \& Wolk, C.P. (1992). Synthesis of nitrogenase in mutants of the cyano- 
bacterium Anabaena sp. strain PCC 7120 affected in heterocyst development or metabolism. J Bacteriol 174, 6025-6032.

Felkner, R. H. \& Barnum, S.R. (1988). Plasmid content and homology of 16 strains of filamentous, nonheterocystous cyanobacteria. Curr Microbiol 17, 37-41.

Figurski, D. H. \& Helinski, D. R. (1979). Replication of an origincontaining derivative of plasmid RK2 dependent on a plasmid function provided in trans. Proc Natl Acad Sci US.A 76, 1648-1652.

Figurski, D., Meyer, R., Miller, D. S. \& Helinski, D. R. (1976). Generation in vitro of deletions in the broad host range plasmid $\mathrm{RK} 2$ using phage $\mathrm{Mu}$ insertions and a restriction endonuclease. Gene 1, 107-119.

Grant, S. G., Jesse, J., Bloom, F. R. \& Hanahan, D. (1990). Differential plasmid rescue from transgenic mouse DNAs into Eschericbia coli methylation-restriction mutants. Proc Natl Acad Sci US A 87, 4645-4649.

Herdman, M. (1987). Akinetes: structure and function. In The Cyanobacteria, pp. 227-250. Edited by P. Fay \& C. van Baalen. Amsterdam: Elsevier.

Herdman, M. \& Rippka, R. (1988). Cellular differentiation: hormogonia and baeocytes. Methods Enzymol 167, 232-242.

Hirosawa, T. \& Wolk, C. P. (1979). Isolation and characterization of a substance which stimulates the formation of akinetes in the cyanobacterium Cylindrospermum licheniforme Kutz. J Gen Microbiol $114,433-441$.

Houmard, J. \& Tandeau de Marsac, N. (1988). Cyanobacterial genetic tools: current status. Methods Enzymol 167, 808-847.

Ish-Horowicz, D. \& Burke, J. F. (1981). Rapid and efficient cosmid cloning. Nucleic Acids Res 9, 2989-2998.

Johansson, C. \& Bergman, B. (1994). Reconstitution of the Gunnera manicata Linden symbiosis: cyanobacterial specificity. New Phytol 126, 643-652.

Lambert, G. R. \& Carr, N. G. (1984). Resistance of DNA from filamentous and unicellular cyanobacteria to restriction endonuclease cleavage. Biocbim Biopbys Acta 781, 45-55.

Meeks, J. C. (1990). Cyanobacterial-bryophyte associations. In Symbiotic Cyanobacteria, pp. 43-63. Edited by A. N. Rai. Boca Raton, FL: CRC Press.

Meeks, J. C., Wycoff, K. L., Chapman, J. S. \& Enderlin, C. S. (1983). Regulation of expression of nitrate and dinitrogen assimilation by Anabaena species. Appl Environ Microbiol 45, 1351-1359.

Meeks, J. C., Enderlin, C. S., Joseph, C. M., Chapman, J. S. \& Lollar, M. W. L. (1985). Fixation of $\left[{ }^{13} \mathrm{~N}\right] \mathrm{N}_{2}$ and transfer of fixed nitrogen in the Anthoceros-Nostoc symbiotic association. Planta 164 406-414.

Potts, M. (1989). Isolation of plasmids from cyanobacteria. $B R L$ Focus 6, 4-6.

Raleigh, E. A. (1992). Organization and function of the $m c r B C$ genes of Escherichia coli K-12. Mol Microbiol 6, 1079-1086.

Rippka, R., Deruelles, J., Waterbury, J. B., Herdman, M. \& Stanier, R. Y. (1979). Generic assignments, strain histories and properties of pure cultures of cyanobacteria. J Gen Microbiol 111, 1-61.

Sambrook, J., Fritsch, E. F. \& Maniatis, T. (1989). Molecular Cloning: a Laboratory Manual, 2nd edn. Cold Spring Harbor, NY: Cold Spring Harbor Laboratory.

Shestakov, S. V. \& Reaston, J. (1987). Gene transfer and hostvector systems of cyanobacteria. Oxford Surv Plant Mol Cell Biol 4, 137-166.

Steinberg, N. A. \& Meeks, J. C. (1991). Physiological sources of reductant for nitrogen fixation activity of Nostoc sp. strain UCD 7801 in symbiotic association with Anthoceros punctatus. J Bacteriol $173,6227-6233$.

Stuttzman, K. \& Gendel, S. M. (1985). A rapid method for identifying plasmids in cyanobacteria. FEMS Microbiol Lett 26, 337-348.

Vieira, J. \& Messing, J. (1982). The pUC plasmids, an M13mp7derived system for insertion mutagenesis and sequencing with synthetic universal primers. Gene 19, 259-268.

Wallis, J. G. (1993). Development of genetic tools for the cyanobacterium Nostoc sp. strain ATCC 29133. PhD thesis, University of California, Davis.

Wolk, C. P. (1982). Heterocysts. In The Biology of Cyanobacteria, pp. 359-386. Edited by N. G. Carr \& B. A. Whitton. Oxford: Blackwell Scientific Publications.

Wolk, C. P. (1991). Genetic analysis of cyanobacterial development. Curr Opin Genet Dev 1, 336-339.

Wolk, C. P., Vonshank, A., Kehoe, P. \& Elhai, J. (1984). Construction of shuttle vectors capable of conjugative transfer from Escherichia coli to nitrogen fixing filamentous cyanobacteria. Proc Natl Acad Sci US A 81, 5355-5359.

Wolk, C. P., Cai, Y. \& Panoff, J-M. (1991). Use of a transposon with luciferase as a reporter to identify environmentally responsive genes in a cyanobacterium. Proc Natl Acad Sci US A 88, 5355-5359.

Received 8 July 1994; revised 6 September 1994; accepted 8 September 1994. 